Copyright (C) 2021 by Cherkas Global University

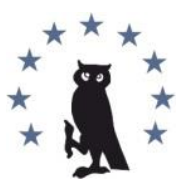

Published in the the USA

International Journal of Media and Information Literacy

Has been issued since 2016.

E-ISSN: $2500-106 \mathrm{X}$

2021. 6(2): 396-405

DOI: 10.13187/ijmil.2021.2.396

https://ijmil.cherkasgu.press

\title{
Media Representation of the Image of the Russian Political Leader in Western Online Media (On the Material Daily News and Der Spiegel)
}

\author{
Lyudmila Seliverstova $^{a}{ }^{, *}$, Anastasia Levitskaya ${ }^{\mathrm{b}}$, Ilya Seliverstov ${ }^{\mathrm{c}}$ \\ a Southern Federal University, Russian Federation \\ b Taganrog Institute of Management and Economics, Russian Federation \\ c Belgorog National Research University, Russian Federation
}

\begin{abstract}
This article seeks to contribute to a theory of media's construction of reality - study the ways mass media use to shape a public figure's image, on the example of the Russian political leader's representation in foreign media. The main focus of the research is on the linguistic means by which this image is created and reinforced. The data are drawn from a selection of publications of the American newspaper Daily news and the German magazine Der Spiegel in the online format from 2000 to 2004 and from 2018 to 2020 .

The authors examined is a striking and by far not unique example of how the world media construct the social reality for a contemporary man. In most cases, creating the media image of the President of Russia V. Putin, the Daily News and Der Spiegel appeal to readers' negative emotions. Although on the pages of the German edition over the last three years it was possible to identify language means that positively characterize the leader of Russia, their share is insignificant. Since the selection of linguistic means directly affects what image will be formed in the mind of the reader, it can be concluded that the Western media deliberately form a predominantly negative media image of the Russian president, thereby manipulating the opinion of the German-speaking and English-speaking people. It should be admitted that powerful structures of information warfare and anti-Russian propaganda have long been developed in the West, and this propaganda itself, often mixed with Russophobia, has practically turned into a factor of global politics.

Keywords: media, media text, representation, media political discourse, political leader, linguistic means, analysis.

\section{Introduction}

Today, a person receives most of the information via media texts from various resources, including online newspapers and magazines. However, the mass media have long ceased to be the actual means of transmitting information, but mainly have moved into the category of means of manipulating the public consciousness. In the modern world, information and psychological impact on the minds and social behavior of people is becoming one of the main threats. With the help of linguistic means, the media impose a system of values and ideas about objects of reality, thereby constructing a certain world picture on the whole, and in particular, they shape the media images of nations, states and their political leaders, which are being fixed in people's minds and acquire special significance in the era of information wars. In this regard, it is important to study the linguistic means used in foreign media to form the media image of the Russian political leader.
\end{abstract}

\footnotetext{
${ }^{*}$ Corresponding author

E-mail addresses: seliverstova_23@mail.ru (L. Seliverstova)
} 


\section{Materials and methods}

The materials of the study are publications of the American newspaper Daily news and the German magazine Der Spiegel in the online format from 2000 to 2004 and from 2018 to 2020, in which the President of the Russian Federation V.V. Putin has been mentioned. Both media are popular and respected by readers. Thus, the Daily News is the sixth largest daily newspaper in New York City in the United States, founded in 1919. The newspaper has won eleven Pulitzer Prizes. Spiegel Online (SPON) is one of the most read and cited news sites in German. It was founded in 1994 as an online version of the German news magazine Der Spiegel with a staff of independent journalists. The editor-in-chief is currently journalist M. Müller von Blumenkron. At first, the style of the publication was completely copied from the best American and British publications, especially Times magazine.

In the present work, we rely on the concept of social construction of reality by P. Berger and T. Luckmann (Berger, Luckmann, 1995). The methodological basis of this research is a hypothetical-deductive method associated with the analysis and generalization of theoretical and practical material. The development of the main categories and the analysis of theoretical material is carried out on the basis of conceptual analysis, as well as a descriptive-comparative method, which allow comparing various approaches and theories to the study of media-political discourse, identifying their advantages and disadvantages to determine their own research paradigm.

The research was carried out at the intersection of discourse theory, media linguistics and political linguistics, the central concepts of which are media-political discourse, media image, media text. The selection and analysis of lexical means of forming the media image of the Russian president has been carried out by means of continuous sampling of material, contextual analysis, by the method of comparative analysis of texts in different languages.

\section{Discussion}

Linguists note that the term "discourse" in linguistics is famous for its ambiguity. Thus, discourse can be defined as a coherent text in combination with extralinguistic, pragmatic, sociocultural, psychological and other factors; the text taken in the event aspect; as speech, "immersed life" (Arutyunova, 1998: 136-137), "appropriated by the speaker" (Arutyunova, 1998: 136-137); as a "text immersed in the situation of communication", which allows for many dimensions and complementary approaches in the study, including pragmalinguistic, psycholinguistic, structural-linguistic, linguocultural, sociolinguistic (Karasik, 2000: 5-6); as a text in its dynamics, correlated with the main subject, with the "Ego" of the entire text with a person who creates the text (Stepanov, 1981: 332); as a set of interactions between the representations of certain social groups (for example, a politician - a citizen) (Protasova, 1999: 144). In all these definitions, the concept of discourse presupposes a set of linguistic means with the conditions of communication.

As the most relevant to this study, let us dwell on the concept of discourse in the light of "a set of correlated texts functioning in the same communicative sphere" (Chernyavskaya, 2014: 112). V.E. Chernyavskaya emphasizes that the texts combined into discourse address one common theme, and the content of the discourse is revealed not in one separate text, but in the complex interaction of many separate texts. According to this interpretation, examples of discourse are political, legal, media ones, etc. This work focuses on the media-political discourse arising in the process of close interaction of political and media discourse.

By political discourse, we mean a set of texts united by political themes, the distinctive features of which are "a quick change in the extralinguistic context of the creation and perception of a text, ideological orientation, internal polemics, a simultaneous combination of dialogism and monologue, the use of political argumentation, totalitarianism, intertextuality, mythology, stereotypicality, opposition of the concepts "our", "alien" (Matveeva, 2008: 92) and manipulative orientation. We also agree with M.V. Grechikhin, who describes media discourse as "a socially regulatory mechanism that organizes mass consciousness through the formation and replication of socially significant cognitive, axiological and regulatory meanings" (Grechikhin, 2008: 6). That is, the media create, construct another reality, a picture of the world, form ideological meanings, thus influencing the opinion of society and manipulating it. Within the framework of this study, mediapolitical discourse is considered as a product of the interaction of political and media discourses, the main task of which is to form public opinion. 
Information media resources form an attitude to the phenomena of reality, including constructing media images of individual personalities. There are many interpretations of the concept of "media image". So, M.N Cherkasova defines a "media image" as a product of the media industry, in which political, financial, economic, socio-cultural, psycholinguistic means and methods of creating a particular media phenomenon are involved (Cherkasova, 2010: 256). $\mathrm{N}$. Luhmann argues that a "media image" is an image of a second reality, since the media do not state facts, but interpret them, are a kind of "mirror" or a second reality (Luhmann, 1996: 12-13). However, this "second reality" can often have little in common with the "first" one, existing in reality, and the mirror may be crooked.

In our opinion, the concept of social construction of reality by P. Berger and T. Luckmann is very productive in the study of the role of media in the life of society. In their work, scientists operate with the concept of "everyday knowledge" and define it as knowledge that any individual shares with other people in the usual self-evident routine of everyday life. Researchers argue that the reality of everyday life is taken for granted, that is, it does not involve analysis. Its existence is taken for granted (Berger, Luckmann, 1995).

This "everyday knowledge" in the media space constructs myths. The theorist and practitioner of mythology Roland Barthes argues that myths are capable of "deforming reality" (Barthes, 2019: 280). According to Barthes, a myth is a word, a communication system, a message. At the same time, it is a form enclosed in a historical framework, used in certain conditions, filled with a certain social content. Meanwhile, the mythical word (concept) is considered not only and not so much as a unit of natural language, but as a sign of a semiological system (Barthes, 2019: 265-267). The scientist emphasizes that "any semiological system is a system of values; now the myth consumer takes the signification for a system of facts: myth is read as a factual system, whereas it is but a semiological system" (Barthes, 2019: 291).

Thus, a modern person exists inside the media space, which constructs myths, wrapping them in certain media images, thereby creating the social reality, reflecting, shaping and distorting the system of human value orientations (Camarero et al., 2019; Fedorov, Levitskaya, 2021; Levitskaya, Fedorov, 2021).

\section{Results}

In the course of the analysis of the linguistic means used by the authors of German and English-language media texts to form the media image of the Russian political leader, various means of linguistic expressiveness were identified, among which the bulk are quotations and various tropes. The vast majority of these means create a negative image of the President of Russia and thereby purposefully tarnishing the image of Russia and Russians in general.

The entire spectrum of expressive means is used as linguistic means of media representation of the head of the Russian Federation: epithets, comparisons, metaphors, personification, metonymy, synecdoche, allegory, hyperbole, lithote, paraphrase, oxymoron, irony, phraseological units, etc. We are not going to analyze each of them within the current study's framework. We only note that a special place in the media is occupied by a metaphor, which is a necessary and effective method of representing reality or attitudes towards it, since it permeates our everyday life, and not only language, but also thought and action. Our usual conceptual system, in terms of which we think and act, is metaphorical in nature (Lakoff, Johnson 1990: 387).

In the American media texts of 2000-2004, they wrote about the Russian president that he is an unfamiliar person without a past, "blank slate" (Nelson, 2000), "former KGB agent" (Sisk, 2000a) or "former KGB spy" (Sisk, 200ob), who "launched a KGB- style campaign of harassment against a free and fair press" (Daily News, 2000).

The German media also often resort to metaphorical means, for example, during the first period of the presidency, they wrote about the rapid rise to power of V.V. Putin was due to his successful counterterrorism activities: "Der gnadenlose Kampf gegen Terroristen", der auch Hunderten von Zivilisten das Leben kostete, spielte die Schlüsselrolle beim rasanten Aufstieg Putins an die Macht" (Essipov, 2000). The author of the text creates the image of a "merciless" careerist who reached the pinnacle of power only despite the fact that there were some casualties on this path, but also largely due to activities that "cost the lives" of hundreds of people. At the same time, the journalist does not mention the danger of the policy of flirting with terrorists, whose victims have become hundreds of people. 
The policy of the Russian president is described as being conducted by a "strong hand": "Politik der harten Hand" (Gebauer, 2004) or "In seiner Person erkannten die Russen die längst ersehnte starke Hand", die nach neun Regierungsjahren des schwachen und unberechenbaren Jelzins wieder mal Sicherheits- und Großmachtgefühle vermitteln könnte" (Essipov, 2000). And Russia is called "Putin's empire", in which a special role is assigned to the secret police: "In Putins Reich wachsen rasch die Aufgaben der Geheimpolizei” (Klussmann, 2000). These linguistic means create the image of a tough sole ruler, a "monarch", thereby referring to the past of Russia and indirectly indicate the past activities of the current president during his previous service in the security agency.

The perception of Russia as a state with a totalitarian type of government leads to comparison between the leaders of Russia and China, who are openly called "dictators and tyrants": "Biden got on the bad side of Kim's mouthpiece when he accused Trump of sucking up to "dictators and tyrants" like Kim and Russian President Vladimir Putin (Goldiner, 2019). And it is not surprising, because the mass media reflects the rhetoric of the politicians of their countries. Minister of Foreign Affairs of the Russian Federation S.V. Lavrov also noted that, as bearers of authoritarianism, these two states are designated as the main "obstacle" to the implementation of the "democratic" course by the countries of the North Atlantic Alliance (Lavrov, 2021). Der Spiegel, reporting on the war in Syria, calls the head of the Russian Federation on a par with the presidents of Turkey and Syria an "autocrat": "Die Autokraten Erdogan und Putin und der Diktator Assad entscheiden über Leben und Tod" (Titz, 2020). Thus, the Western media are purposefully weaving in the enemy's image of the Russian leader, and therefore "painting" Russian citizens as people whom one needs to fight with, whom one needs to defend oneself from. Hence, the question naturally arises: what about German tolerance? Why is Germany diverse ("Deutschland ist vielfältig"), while the rest of the world is clearly divided into "correct" democracies and autocracies?

The President of Russia is harshly criticized in the Western media in connection with the long term of office, amendments to the Constitution of the Russian Federation, etc. The following namings are found in media texts: "the longtime Russian president" (Gifford, 2020), "Zar für die nächsten Jahre"(German. Tsar for the years to come) (Esch , 2020a) and others. American media compare V.V. Putin with Stalin and accuse of seizing power: "Lawmakers in Russia voted Wednesday to change the country's constitution so that term limit restrictions will not apply to the former KGB agent, who is slated to leave office in four years ... Only Joseph Stalin, who led the Soviet Union from 1927 to 1953, served the nation longer ... Roughly 200 protesters showed up near the Kremlin Tuesday night to voice objection to Putin's apparent power grab" (Niemietz, 2020). The German media create an image of deceived, disoriented Russians who were lured to the ballot boxes and forced to vote for changes to the Constitution of the Russian Federation. The President of Russia is called "Hütchenspieler" (German, a swindler) (Esch, 2020a).

At the same time, it is noted that the removal of the term limits for the presidency is only one of the 206 amendments put to the vote: "Um die Verwirrung des Wahlvolks vollständig zu machen, ist Putins Befreiung von der Amtszeitbeschränkung nur eine von 206 Verfassungsänderungen (Esch, 2020b). The phrase of the Russian president "We are not voting for changes in the Constitution, we are voting for the country in which we want to live" was interpreted as a poorly veiled call for his own indefinite domination in the Kremlin: "Was er in seinem schlecht verhüllten Wahlaufruf verschwieg, war die Tatsache, dass es um ihn selbst geht und die Entfristung seiner Herrschaft im Kreml" (Esch, 202ob). At the same time, the many years of being in power of their own political leaders (Angela Merkel as Federal Chancellor of Germany - for 16 years, Helmut Kohl - 16 years, Konrad Adenauer - 14 years) is taken for granted, and their repeated re-election to the position is seen as an expression of citizens' support of the leaders' political and economic course.

Since V.V. Putin has led Russia for several decades and has not left the pages of the media, it seems worthwhile to trace the transformation of the image of the Russian leader, formed by the foreign press. To do this, in publications of two periods from 2000 to 2004 and 2018 to 2020 the nominations, with the help of which the image of the Russian president was created in the American newspaper Daily news and the German Der Spiegel, were selected (Table 1).

In German-language media texts of the period 2000-2004 the activities of the Russian head of state were constantly associated with his work in the security agencies, which is confirmed by the nominations "unbekannter Geheimdienstler", "KGB-Oberst", "der damalige FSB-Chef" (Essipov, 2000) or "der Ex-KGB-Agent" (Mettke, 2002). Meanwhile, the media used stylistic means that form the media image of an exceptionally incompetent, inexperienced leader who has to prove that 
he is able to rule the country, for example, the metaphors "Putins schwerste Prüfung", "ernste Probe" (Mrozek, 2002), the oxymoron "Die hilflose starke Hand or"der mächtigste Mann im Riesenreich machtlos" (Essipov, 2000), but at the same time, the lack of experience did not prevent him from pursuing an independent tough policy, as a result of which there are nominations "der zu selbstständig gewordene Präsident" (the President who has become too independent) and the metaphor "ersehnte "starke Hand" (the sought after strong hand) (Essipov, 2000).

Table 1. Transformation of the media image of the Russian president in the magazine Der Spiegel

\begin{tabular}{|c|c|c|c|}
\hline 20OO-2004, German & Translation in English & $\begin{array}{l}\text { 2O18-2O2O, } \\
\text { German }\end{array}$ & $\begin{array}{l}\text { Translation in } \\
\text { English }\end{array}$ \\
\hline $\begin{array}{l}\text { Unbekannter } \\
\text { Geheimdienster, } \\
\text { KGB-Oberst, } \\
\text { der damalige FSB-Chef, } \\
\text { der Ex-KGB-Agent, } \\
\text { der Kamerad Putin aus St. } \\
\text { Petersburg, } \\
\text { der neue russische } \\
\text { Staatschef, } \\
\text { gottloser } \\
\text { Geheimdienstoffizier, } \\
\text { Christ, tief gläubiger } \\
\text { Mensch, streng Gläubige, } \\
\text { glaubensstarker Zar, } \\
\text { ersehnte "starke Hand" der } \\
\text { zu selbstständig gewordene } \\
\text { Präsident, } \\
\text { der Erneuerer im Kreml, } \\
\text { Aufklärer Putin, } \\
\text { der mächtigste Mann im } \\
\text { Riesenreich, } \\
\text { der Herr im Kreml, } \\
\text { der Kremlherr, } \\
\text { der Kremlchef, } \\
\text { ausgemachter Konformist, } \\
\text { Pragmatiker, } \\
\text { Schröders großer Bruder, } \\
\text { Schröders Kumpel, } \\
\text { der hohe Gast }\end{array}$ & $\begin{array}{l}\text { Unknown secret } \\
\text { service, } \\
\text { KGB Colonel, } \\
\text { the then FSB boss, } \\
\text { the ex-KGB agent, } \\
\text { comrade Putin from St. } \\
\text { Petersburg, } \\
\text { the new Russian head } \\
\text { of state, } \\
\text { godless intelligence } \\
\text { officer, } \\
\text { Christian, deeply } \\
\text { believing person, strict } \\
\text { believer, strong faithful } \\
\text { tsar } \\
\text { Longed-for "strong } \\
\text { hand" the president } \\
\text { who has become too } \\
\text { independent, } \\
\text { the innovator in the } \\
\text { Kremlin, enlightener } \\
\text { Putin } \\
\text { the most powerful man } \\
\text { in the gigantic empire, } \\
\text { the Kremlin lord, the } \\
\text { Kremlin chief, } \\
\text { outright conformist, } \\
\text { pragmatist, } \\
\text { Schröder's big brother, } \\
\text { Schröder's buddy, } \\
\text { the distinguished guest }\end{array}$ & $\begin{array}{l}\text { ein gewalttätiger } \\
\text { Autokrat, } \\
\text { Gewinner im } \\
\text { syrischen } \\
\text { Bürgerkrieg, } \\
\text { Despot, } \\
\text { der starke Mann } \\
\text { Russlands, } \\
\text { der Kümmerer, } \\
\text { der gute } \\
\text { Landesvater, } \\
\text { der } \\
\text { Landesverteidiger, } \\
\text { Wohltäter, } \\
\text { Milder Präsident, } \\
\text { der Modernisierer, } \\
\text { der Reformer } \\
\text { harter } \\
\text { Naturbursche, } \\
\text { Träger des } \\
\text { schwarzen Gürtels } \\
\text { in Judo, } \\
\text { Macho, } \\
\text { Albtraumtänzer, } \\
\text { der Eismann, } \\
\text { der } \\
\text { Hütchenspieler, } \\
\text { Trumps Helfer }\end{array}$ & $\begin{array}{l}\text { a violent autocrat, } \\
\text { winner in the } \\
\text { Syrian civil war, } \\
\text { Despot, } \\
\text { the strong man of } \\
\text { Russia, } \\
\text { the carer, } \\
\text { the good father of } \\
\text { the country, } \\
\text { the defender, } \\
\text { benefactor, } \\
\text { Mild President, } \\
\text { the modernizer, } \\
\text { the reformer, } \\
\text { tough } \\
\text { outdoorsman, } \\
\text { wearer of the black } \\
\text { belt in judo, } \\
\text { Macho, } \\
\text { Nightmare, } \\
\text { the ice cream man, } \\
\text { the shell player, } \\
\text { Trump's helper }\end{array}$ \\
\hline
\end{tabular}

During the beginning of the Russian political leader's term, the German press was also sarcastically about his religious beliefs, putting forward hypotheses regarding the "transformation of a godless secret police officer into a deeply religious person": "wann die Wandlung des gottlosen Geheimdienstoffiziers zum streng Gläubigen geschah" (Klussmann, 2001). In the same ironic form, the support of the Russian President's Orthodox Church in strengthening the state was emphasized: "Und die Kirchenführung nimmt dankbar zur Kenntnis, wenn ihr glaubensstarker Zar ihren Beitrag" zur patriotischen Erziehung und zur Stärkung des Staates rühmt” (Klussmann, 2001) It is not clear in this case why the religious beliefs of the Russian president is presented in the Western media as proof of his insincerity: "Wann die Bekehrung des Kremlherrn stattgefunden hat, verriet der Geistliche nicht" (The clergyman did not reveal when the Kremlin lord's conversion took place) (Klussmann, 2001). In Russia, from time immemorial, church has played a large role in society.

In the Soviet period, belief in God was considered a relic of the past, since the communist ideology assumed the eradication of any religious feelings. However, it is not without reason that Russian wisdom says: Man proposes, but God disposes. The Soviet government did not succeed in 
eradicating religious feelings from the population. In the USSR, Russian Orthodox Church survived and has revived in modern Russia. Putin prefers not to dwell openly on religious topics and believes that "it is better for a person to keep questions of faith in one's heart: Glaubensfragen sollte "der Mensch lieber in seinem Herzen bewahren" (Klussmann, 2001). Therefore, the words "Wandlung" (change) and "Bekehrung" (conversion) can be regarded as deliberate speech activity aimed at forming a negative media image of the Russian leader.

Quoting Putin's former colleague, Vladimir Usoltsev, Der Spiegel presents the Russian president as a careerist, a convinced conformist who does not believe in the possibility of change in his country, says one thing, but thinks another: "Pragmatiker ..., der das eine denkt und das andere sagt; "ausgemachten Konformisten, der an keinerlei Veränderung in seinem Heimatland glaubt" (Neef, 2003). Here is a quote from Usoltsev's book "Co-worker", overall sympathizing the current president: "Volodya did not at all strive for a career and did not "fuss" in front of his superiors; "Volodya had no signs of a careerist. He was an ordinary hard worker-conformist, resigned to the system..." (Usoltsev, 2004: 230). The contradiction of images created by the ex-colleague of V.V. Putin and a German journalist is obvious.

One cannot fail to note the criticism and caustic irony of the German press regarding the friendly relations between the German Chancellor G. Schröder and V.V. Putin: "Gerhard Schröder und Russlands Präsident Wladimir Putin pflegen ihren eigenen, fast kindlichen Freundschaftskult ... Stolz wie ein Zehnjähriger auf seinen großen Bruder. Gerhard Schröder nach Hamburg gereist, um vor aller Welt seine außergewöhnliche Freundschaft zu demonstrieren" (Gerhard Schröder and Russia's President Vladimir Putin cultivate their own almost childlike cult of friendship ... as proud as a ten-year-old of his big brother. Look here, the German signaled, this is my buddy and we belong together ... After all, Gerhard Schröder traveled to Hamburg to demonstrate his extraordinary friendship to the whole world) (Schmitz, 2004). Relations between the heads of state are characterized by the epithets "childlike", "extraordinary". Basic respect, politeness or tact of the Western media towards the head of another state is non-existent. To cite, German media wrote "bellt Putin ungehalten auf Deutsch" (barked something in response to a question) (Schmitz, 2004). It is not clear what causes more irritation - the Russian president's fluency in German or the content of his answer.

While Western media were ironic about the friendly relations of the Russian president with former German Chancellor G. Schroeder, then only for a hint of those with former American President Donald Trump, the latter was severely criticized for: "Biden ... accused Trump of sucking up to "dictators and tyrants" like Kim and Russian President Vladimir Putin" (Goldiner, 2019). "Trump is knowingly giving aid to the enemy, fighting by their side as they advance against our nation" (Mckew, 2018). Here, by the "enemy" is meant Russia and its President V.V. Putin. Thus, the Western press persistently broadcasts to its citizens that one cannot be friends with Russia, one can only fight/resist it, and that politicians building cooperative relations are to be blamed.

On the occasion of the 2oth anniversary of the Russian president's tenure in power, the German weekly published a collage of 32 photographs with comments illustrating individual milestones of his political leadership and moments in life as a kind of touches to a portrait (20 Jahre .., 2019). Most (56 \%) of the material characterizes V.Putin exclusively from the positive side, for example, the nomination "der starke Mann Russlands", the epithet "bürgernah" is used in relation to the policy pursued taking into account the interests of citizens; $18 \%$ of the information provided gives a negative assessment of the actions of the Russian leader, including quotes by the American President D. Trump with accusations of interference in the US elections. Photographs of the meetings of the President of the Russian Federation with the Chancellors of the Federal Republic of Germany: G. Schröder, who named V.V. Putin as a "pure democrat" - "lupenreiner Demokrat", and A. Merkel, who is "hingegen brüskierte Putin" - "talked harshly" with him. Foreign media often draw attention to the excellent physical shape of the Russian president, resorting to such nominations as "the horse-riding strongman, the 67-year-old strongman, the Russian strongman Vladimir Putin" or "harter Naturbursche".

The analyzed publication is a clear confirmation of this: 15 out of 32 facts about the Russian president are photographs on horseback, fishing, hunting, in a capsule sinking to the bottom of the sea, in the sky on a paraglider, etc. Comments on some of the photographs are quite ironic, for example, "Unerschrocken steuerte Putin das Boot dicht an Bären vorbei - und bediente damit wieder einmal das Macho-Image, das er in seiner Karriere schon oft zu nutzen versuchte" 
(Undaunted, Putin steered the boat right past the bear - and once again used the macho image that he has tried to exploit many times in his career).

With the words "tried to use the macho image," the media form the image of an "insincere" person. The last two photographs are selected and captioned as to intimidate the reader and to generate distrust. In the one picture, the President is feeding a moose cub, and the caption goes "Meistens hart, manchmal zart: Nicht immer gibt Putin bei seinen Aktionen den Macho. Manchmal - wenn auch selten - zeigt er sich ganz weich" (Mostly tough, sometimes tender: Putin does not always act macho in his actions. Sometimes - albeit rarely - he is very soft). And in the last photo, a woman is holding a portrait of the President with the inscription "That's all", and the commentary informs about protest movements in Russia and citizens' discontent (20 Jahre..., 2019). Thus, the portrait of the Russian president is very contradictory and forms the image of a strong politician, a manly person and at the same time an "insidious enemy" not to be trusted.

The fact of humanitarian aid from Russia to the United States during the most acute period of the spread of the Covid pandemic in America was presented by the German media as "überraschend" (unexpected), arguing this assessment with "tense relations" between countries (“... weil die Beziehungen zwischen Moskau und Washington seit Jahren angespannt sind”), and therefore insincere: the publication's headline states that the Russian President "poses as/pretends to be Trump's helper" ("Putin inszeniert sich als Trumps Helfer") (Corona News-Update, 2020).

The traditional multi-hour press conferences of the President of the Russian Federation with journalists are presented by the Western mass media as a kind of a show in which the head of state positions himself as a reformer, benefactor, defender of the country's interests: "Vier Stunden lang lief die jährliche Pressekonferenz des russischen Präsidenten Wladimir Putin - und sie immer mehr zur Presseshow. Widerspruch oder gar Protest gegen den Kurs der russischen Regierung gab es nur im zugelassenen Rahmen. Stattdessen durfte sich Putin als Modernisierer, Reformer, Kümmerer und Landesverteidiger geben" (Hebel, 2018). And although the nominations "Modernisierer, Reformer, Kümmerer und Landesverteidiger" are used in an ironic manner, we would like to believe that the Western media, according to the Russian proverb, accept the fact that there is some truth behind every joke.

Table 2. Nominations shaping the media image of the Russian President in the Daily News

\begin{tabular}{|l|l|}
\hline \multicolumn{1}{|c|}{$2000-2004$} & \multicolumn{1}{|c|}{ 2018-2020 } \\
\hline a former career KGB & the 67-year-old former KGB agent \\
officer & this Kremlin former KGB officer \\
a former KGB official & dictator and tyrant \\
ex-KGB agent & the Russian autocrat \\
ex-KGB spy & despot, criminal, murderer and unmoral bum \\
old Cod Warrior & Tsar Vladimir \\
an "enforcer" and political & the longtime Russian president \\
strategist & the most powerful man in the world \\
the Gray Cardinal & the shady Russian leader \\
beleaguered president & the outspoken and famously LGBTQ-unfriendly president of the \\
the grandson of one of & Russia Federation \\
Joseph Stalin's cooks & enemy \\
brilliant bureaucrat & the resonification of evil \\
& the horse-riding strongman \\
& the 67-year-old strongman \\
& the Russian strongman Vladimir Putin \\
\hline
\end{tabular}

As Tab. 1 demonstrates, the nominations of the Russian leader in the German press have undergone qualitative transformation over the years. However, no significant change can be identified in the American media space (Tab. 2) apart from the more outspoken animosity of some of the epithets. Ignoring 20 years experience of state leadership, the head of the Russian Federation is persistently presented in American media as a "KGB agent". For example, commenting on the amendments to the Russian constitution, the American press calls V.V. Putin's "former KGB agent": "Lawmakers in Russia voted Wednesday to change the country's constitution so that term limit restrictions will not apply to the former KGB agent... " (Niemitz, 2020). Having 
attached the label, the American media insist on it, despite the absurdity of the media image being drawn, which again proves the failure even to try to be objective, analyze the concrete situations, and not be guided by a bias. In this regard, it is not possible to trace the change in the media image of the Russian political leader in the American media.

\section{Conclusion}

In the era of mediatization, the media have an impact on almost all spheres of society. Currently, the dominance of the manipulative function is observed, the media do not so much inform as they influence, shaping the reader's opinion about certain events. As a tool of influence, the media use linguistic means with the help of which certain media images are formed by journalists. Due to the fact that the media are the main vehicles of presenting political reality to society, there is a close interaction of media and political discourses, and this, in turn, leads to the formation of media-political discourse, enshrined in media texts.

The material we have examined is a striking and by far not unique example of how the world media construct the social reality for a contemporary man. In most cases, creating the media image of the President of Russia V.V. Putin, the Daily News and Der Spiegel appeal to readers' negative emotions. Although on the pages of the German edition over the last three years it was possible to identify language means that positively characterize the leader of Russia, their share is insignificant. Since the selection of linguistic means directly affects what image will be formed in the mind of the reader, it can be concluded that the Western media deliberately form a predominantly negative media image of the Russian president, thereby manipulating the opinion of the German-speaking and English-speaking people. It should be admitted that powerful structures of information warfare and anti-Russian propaganda have long been developed in the West, and this propaganda itself, often mixed with Russophobia, has practically turned into a factor of global politics.

\section{References}

20 Jahre.., 2019 - 20 Jahre Putin. Der Spiegel. 09.08.2019. [Electronic resource]. URL: https://www.spiegel.de/fotostrecke/naturbursche-und-kremlchef-20-jahre-putin-fotostrecke170071.html

Arutyunova, 1998 - Arutyunova, N.D. (1998). Diskurs Yazykoznanie. Bol'shoi entsiklopedicheskii slovar' [Discourse. Linguistics. The Great Encyclopedia]. Moscow. [in Russian]

Barthes, 2019 - Barthes, R. (2019). Mifologii [Mythologies]. Moscow. [in Russian]

Berger, Luckmann, 1995 - Berger, P., Luckmann, T. (1995). Sotsial'noe konstruirovanie real'nosti. Traktat po sotsiologii znaniya [Social construction of reality. A treatise on the sociology of knowledge]. Moscow. [in Russian]

Camarero et al., 2019 - Camarero, E., Fedorov, A., Levitskaya, A. (2019). Audiovisual and media literacy for social change. The Routledge Handbook of Positive Communication: Contributions of an Emerging Community of Research on Communication for Happiness and Social Change: 356-363.

Chemyavskaya, 2014 - Chernyavskaya, V.E. (2014). Lingvistika teksta. Lingvistika diskursa [Text linguistics. Linguistics of discourse]. Moscow. [in Russian]

Cherkasova, 2010 - Cherkasova, M.N. (2010). Mediasobytie i mediaobraz s tochki zreniya medialingvistiki i mediakritiki (na primere yazyka vrazhdy) [Media event and media image from the point of view of media linguistics and media criticism (on the example of hate speech)] Nauchnye Vedomosti. 18: 250-257. [in Russian]

Corona News-Update, 2020 - Putin inszeniert sich als Trumps Helfer. Der Spiegel. 31.03.2020. [Electronic resource]. URL: https://www.spiegel.de/wissenschaft/medizin/coron avirus-news-amdienstag-die-wichtigsten-entwicklungen-zu-covid-19-und-sars-cov-2-a-b41ef41f-d46b-4cec-a8be-fb6 b33fe2092

Daily News, 2000 - Putin must end war on press. New York Daily News. 23.12.2000. [Electronic resource]. URL: https://www.nydailynews.com/archives/opinions/putin-war-pressarticle-1.885416

Esch, 2020a - Esch, Ch. (2020a). Traktor gegen Stimmen. Der Spiegel. 01.07.2020. [Electronic resource]. URL: https://www.spiegel.de/ausland/russland-wladimir-putin-und-die-seltsamevolksabstimmung-ueber-die-verfassung-a-8df854fa-1e5o-4e32-96f3-6adf6333baf4 [in German] 
Esch, 2020b - Esch, Ch. (2020b). Putin, der Hütchenspieler. Der Spiegel. 17.02.2020. [Electronic resource]. URL: https://www.spiegel.de/politik/ausland/wladimir-putin-huetchen spieler-der-macht-a-00000000-0002-0001-0000-000169470938

Essipov, 2020 - Essipov, V. (2020). Die hilflose "starke" Hand. Der Spiegel. 11.08.2020. [Electronic resource]. URL: https://www.spiegel.de/politik/ausland/russland-die-hilflose-starkehand-a-88603.html

Fedorov, Levitskaya, 2021 - Fedorov, A., Levitskaya, A. (2021). Media manipulation and movies. Media Education. 17(1): 64-69. DOI: 10.13187/me.2021.1.64

Fedorov, Levitskaya, 2021 - Fedorov, A., Levitskaya, A. (2021). Theoretical model and technology of anti-Russian propaganda in internet communications of modern Ukraine within the framework of various student groups' media literacy education. Media Education. 17(3): 443-452. DOI: $10.13187 / \mathrm{me} .2021 .3 .443$

Gebauer, 2004 - Gebauer, M. (2004). Putins misslungene Faustpfand-Strategie. Der Spiegel. 07.09.2004. [Electronic resource]. URL: https://www.spiegel.de/politik/ausland/dramain-beslan-putins-misslungene-faustpfand-strategie-a-316981.html

Gifford, 2020 - Gifford, S. (2020). Vladimir Putin denies using body doubles for security purposes. New York Daily news. 27.02.2020. [Electronic resource]. URL: https://www.nydaily news.com/news/world/ny-putin-body-doubles-20200228-rvwcgilxpbfyxpvveihbjevexu-story.html

Goldiner, 2019 - Goldiner, D. (2019). Echoing Trump, North Korea labels Joe Biden 'low IQ'. New York Daily news. 22.05.2019. [Electronic resource]. URL: https://www.nydailynews. com/news/politics/ny-joe-biden-north-korea-low-iq-trump-20190522-z6s2bfdlxbcapeqjhjdz4 kefmestory.html

Grechikhin, 2008 - Grechikhin, M.V. (2008). Sovremennyi russkii mediadiskurs: yazyk intolerantnosti. Ph.D. Dis. [Modern Russian media discourse: the language of intolerance: dis. ... cand. philol. sciences]. Belgorod. [in Russian]

Hebel, 2018 - Hebel, Ch. (2018). Putin, der gute Landesvater. Der Spiegel. 07.09.2004. [Electronic resource]. URL: https://www.spiegel.de/politik/ausland/russland-wladimir-putin-dergute-landesvater-a-1244867.html

Karasik, 2000 - Karasik, V.I. (2000). Yazykovaya lichnost': institutsional'nyi i personal'nyi diskurs: sb. nauch. tr. [Language personality: institutional and personal discourse: collection of articles]. Volgograd. [in Russian]

Klussmann, 2001 - Klussmann, U. (2001). Wandlung aus der Asche. Der Spiegel. 21.12.2001. [Electronic resource]. URL: https://www.spiegel.de/politik/wandlung-aus-der-asche-a -1dob5a2e-0002-0001-0000-000021057508?context=issue

Klussmann, Mettke, 2000 - Klussmann, U., Mettke, J.R. (2000). "Die Duma tanzt". Der Spiegel. 21.12.2001. [Electronic resource]. URL: https://www.spiegel.de/politik/die-duma-tanzt-ae6f6a525-0002-0001-0000-000016961447?context=issue

Lakoff, Johnsen, 1990 - Lakoff , G., Johnsen, M. (1990). Metafory, kotorymi my zhivem [The Metaphors we live by] Teoriya metafory [Metaphor theory]. Moscow. [in Russian]

Lavrov, 2021 - Lavrov, S.V. (2021). O prave, pravakh i pravilakh [About law, rights and rules]. "Kommersant" №109/P. 28.06.2021. [Electronic resource]. URL: https://www.kommers ant.ru/doc/4877702 [in Russian]

Levitskaya, Fedorov, 2021 - Levitskaya, A., Fedorov, A. (2021). Theoretical model of media competence's development of teachers-to-be in the process of the analysis of manipulative media influences. Media Education. 17(2): 323-332. DOI: 10.13187/me.2021.1.323

Luhmann, 1996 - Luhmann N. (1996). Die Realität der Massenmedien. Wiesbaden.

Matveeva et al., 2009 - Matveeva, G.G, Seliverstova, L.N., Samarina , I.V. (2009). Vzaimosvyaz' yazyka i vlasti [The relationship of language and power]. Filosofiya prava. 6: 90-95.

Mckew, 2018 - Mckew, M. (2018). Trump's sickening silence in Helsinki: What the President failed to say about Russia. New York Daily news. 16.07.2018. [Electronic resource]. URL: https://www.nydailynews.com/opinion/ny-oped-trumps-sickening-silence-in-helsinki-20180716story.html

Mettke, 2002 - Mettke, J.R. (2002). „Zeit der Ernte“. Der Spiegel. 29.01.2002. [Electronic resource]. URL: https://www.spiegel.de/politik/zeit-der-ernte-a-6ac16b8e-0002-0001-0000-0000 21304361?context=issue 
Mrozek, 2002 - Mrozek, G. (2002). Putins schwerste Prüfung. Der Spiegel. 25.10.2002. [Electronic resource]. URL: https://www.spiegel.de/politik/ausland/geiseldrama-putins-schwerstepruefung-a-219787.html

Nelson, 2000 - Nelson, L.E. (2000). Russia's prez can't go back to old system. New York Daily news. 31.03.2020. [Electronic resource]. URL: https://www.nydailynews.com/archives /opinions/russia-prez-back-old-system-article-1.864334

Niemietz, 2020 - Niemietz, B. (2020). Vladimir Putin in position to remain Russian president, defy term limit in 2024. New York Daily news. 11.03.2020. [Electronic resource]. URL: https://www.nydailynews.com/news/world/ny-vladimir-putin-stay-in-office-past-2024-term-limit-2 0200311-3h62y47r25fqdliu7nbit2plyq-story.html

Protasova, 1999 - Protasova, E.Yu. (1999). Funktsional'naya pragmatika: variant psikholingvistiki ili obshchaya teoriya yazykoznaniya? [Functional pragmatics: a variant of psycholinguistics or a general theory of linguistics?] Voprosy yazykoznaniya. 1: 142-155. [in Russian]

Schmitz, 2004 - Schmitz, Ch. (2004). Schulter an Schulter. Der Spiegel. 27.12.2004. [Electronic resource]. URL: https://www.spiegel.de/spiegel/print/d-38729256.html

Sisk, 2000a - Sisk, R. (2000a). Bush vows to beef up star wars. New York Daily news. 24.05.2000. [Electronic resource]. URL: https://www.nydailynews.com/archives/news/bushvows-beef-star-wars-article-1.871322

Sisk, 200ob - Sisk, R. (200ob). U.S. Hits Russia over arrest of radio-TV baron. New York Daily news. 15.06.2000. [Electronic resource]. URL: https://www.nydailynews.com/archives /news/u-s-hits-russia-arrest-radio-tv-baron-article-1.872027

Stepanov, 1981 - Stepanov, Yu.S. (1981). V poiskakh pragmatiki (problema sub"ekta) [In search of pragmatics (the problem of the subject)]. Izv. AN SSSR. Ser. lit-ry i yazyka. 4: 325-332. [in Russian]

Titz, 2020 - Titz, Ch. (2020). Autokraten entscheiden über Leben und Tod. Der Spiegel. 05.03.2020. [Electronic resource]. URL: https://www.spiegel.de/politik/deutschland/news-des-ta ges-syrien-gespraeche-in-moskau-a-4ofegdco-54ao-47ea-918b-5cc4cof476o2

Usoltsev, 2004 - Usoltsev, V. (2004). Sosluzhivets [Colleague]. Moscow. [in Russian] 